\title{
Palynological data from sediments of the Hunsrückschiefer type, Lower Devonian of the SW Hunsrück, Germany
}

\author{
RAINER BROCKE, VOLKER KNEIDL, VOLKER WILDE \& WALTER RIEGEL
}

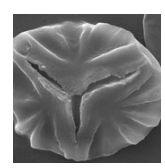

\begin{abstract}
The Devonian Hunsrückschiefer is an outstanding Palaeozoic Fossillagerstätte, widely known for the exceptional preservation of a highly diverse fossil assemblage at the classical sites of Gemünden and Bundenbach. However, biostratigraphical marker fossils are rare and tectonic deformation in the Hunsrück is extremely complex. Therefore, the exact stratigraphic range of the Hunsrückschiefer Lagerstätte and its facies equivalents is still not well understood. Palynological evidence has thus far been very limited because of poor preservation and high thermal alteration. The sediments of the Hunsrückschiefer type (here Zerf Formation) from the newly described Siesbach section have now yielded a rather diverse and reasonably well preserved assemblage of spores and, for the first time, of marine phytoplankton and scolecodonts. Spore assemblages are composed of morphologically simple cryptospores and typical Lower Devonian trilete spores such as Retusotriletes, Apiculiretusispora, Emphanisporites and Streelispora. Phytoplankton assemblages include prasinophytes (Tasmanites, Dictyotidium, Cymatiosphaera, Lophosphaeridium) and various acritarchs (Veryhachium, Micrhystridium, Multiplicisphaeridium, Gorgonisphaeridium). An upper Pragian to lower Emsian (late Siegen) age is suggested for the studied section based on known stratigraphic ranges of the identified spore taxa. Thus, the Zerf Formation appears to be older than the Hunsrückschiefer Lagerstätte at Gemünden and Bundenbach, in which typical Emsian marker species have been observed. The environmental significance of the proportion of marine and terrestrial palynomorphs is briefly discussed. $\bullet$ Key words: Phytoplankton, miospores, Siesbach, Hunsrück, Lower Emsian, Zerf Formation, stratigraphy, facies.
\end{abstract}

BRocke, R., KNEIDL, V., WiLdE, V. \& RIEGEL, W. 2017. Palynological data from sediments of the Hunsrückschiefer type, Lower Devonian of the SW Hunsrück, Germany. Bulletin of Geosciences 92(1), 59-74 (8 figures, 1 appendix table). Czech Geological Survey, Prague. ISSN 1214-1119. Manuscript received September 29, 2016; accepted in revised form March 6, 2017; published online March 27, 2017; issued March 31, 2017.

Rainer Brocke, Senckenberg Forschungsinstitut und Naturmuseum Frankfurt, Senckenberganlage 25, 60325 Frankfurt am Main; Rainer.Brocke@senckenberg.de・Volker Kneidl, Nikolaus Lenau-Straße 22, 55543 Bad Kreuznach. •Volker Wilde, Senckenberg Forschungsinstitut und Naturmuseum Frankfurt, Senckenberganlage 25, 60325 Frankfurt am Main; Volker.Wilde@senckenberg.de•Walter Riegel, Senckenberg Forschungsinstitut und Naturmuseum Frankfurt, Senckenberganlage 25, 60325 Frankfurt am Main; Walter.Riegel@senckenberg.de

The Lower Devonian Hunsrückschiefer (Hunsrück Slate) is worldwide known for exceptionally well preserved pyritized fossils, partly exhibiting soft tissue preservation. The fossils are mainly of marine origin and predominantly found in roof slates (Bartels \& Brassel 1990, Bartels et al. 1998, Jahnke \& Bartels 2000). However, the Hunsrückschiefer has repeatedly been characterized and used in a wider sense on the basis of lithologic criteria as a shale dominated facies between the massive quartzitic sandstones of the so-called Taunusquarzit below and some distinct volcaniclastic intercalations ("porphyroids") above (e.g. Fuchs 1907; Solle 1950; Mittmeyer 1980; Meyer \& Stets 1996; Stets \& Schäfer 2009, 2011). This type of facies is not only found in the type area of the central Hunsrück itself, but extends eastward into the Wester-
wald-Taunus area and northward into the southern Eifel-Mosel area. However, stratigraphic position and regional extent of strata regarded as belonging to the Hunsrückschiefer depend on different opinions and interpretations of lithology, facies and palaeontology. They have been intensely debated for a long time (e.g. Nöring 1939, Engels 1956, Meyer \& Stets 1980, Mittmeyer 1980, Gad 2006, Anderle 2008). To cover the needs for a formal lithostratigraphic terminology the term Hunsrückschiefer Group was proposed for the regions of Hunsrïck and Taunus by Gad (2006) and has been recently adopted in the new stratigraphic table of Germany - STG 2016 (Menning \& Hendrich 2016). However, the situation remains complicated for field geologists and stratigraphers due to intense tectonic deformation of the area and only scattered localities 


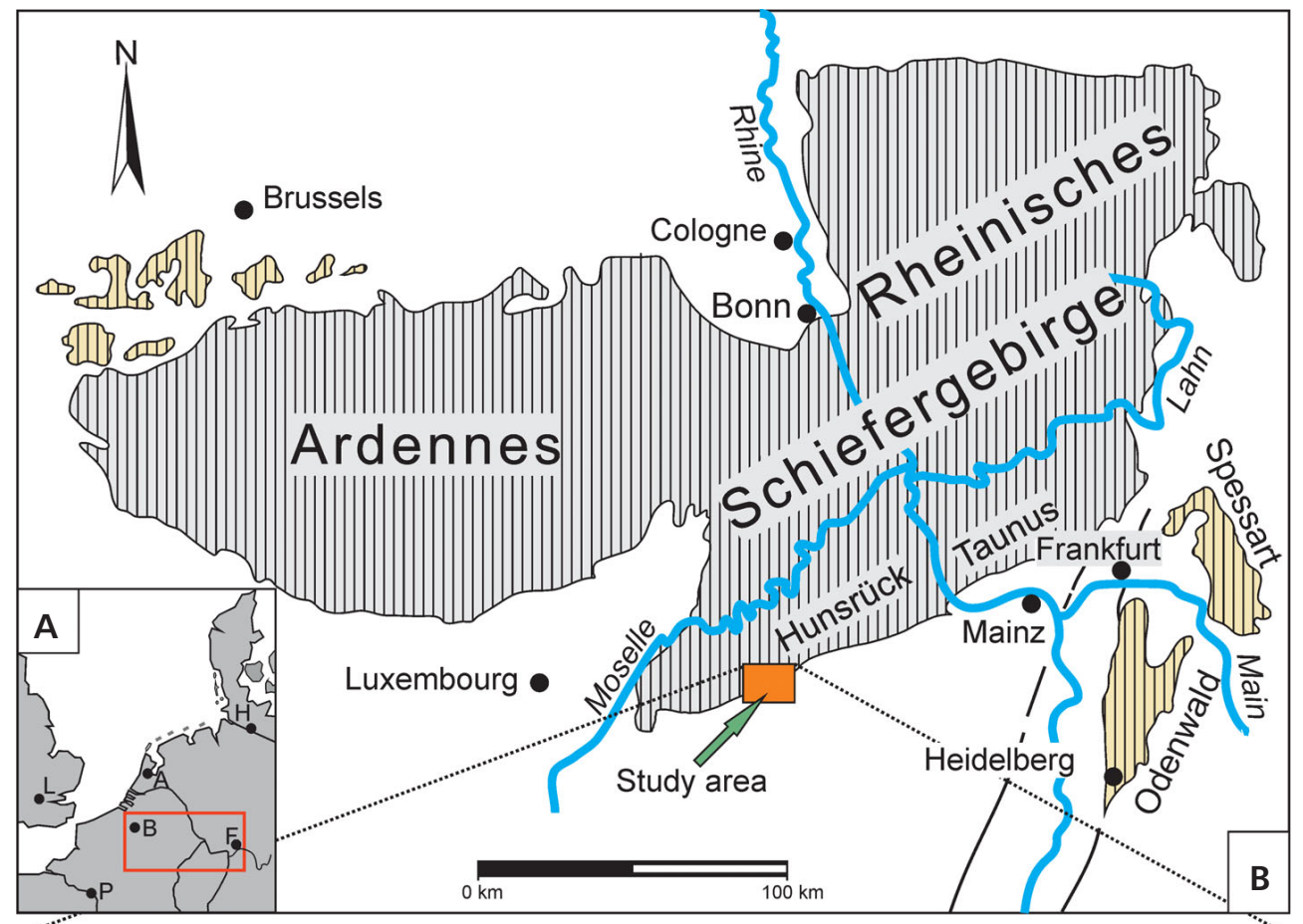

Figure 1. Geographic and geologic position of the Siesbach section. $\cdot \mathrm{A}-$ area of Fig. 1B (outlined in red). • B - map showing study area in relation to Palaeozoic rocks at the surface in western Central Europe (hatching); modified from Kneidl (2011). • C - geological map of the study area (southern Hunsrück) with location of the Siesbach section (modified from Kneidl 2016).

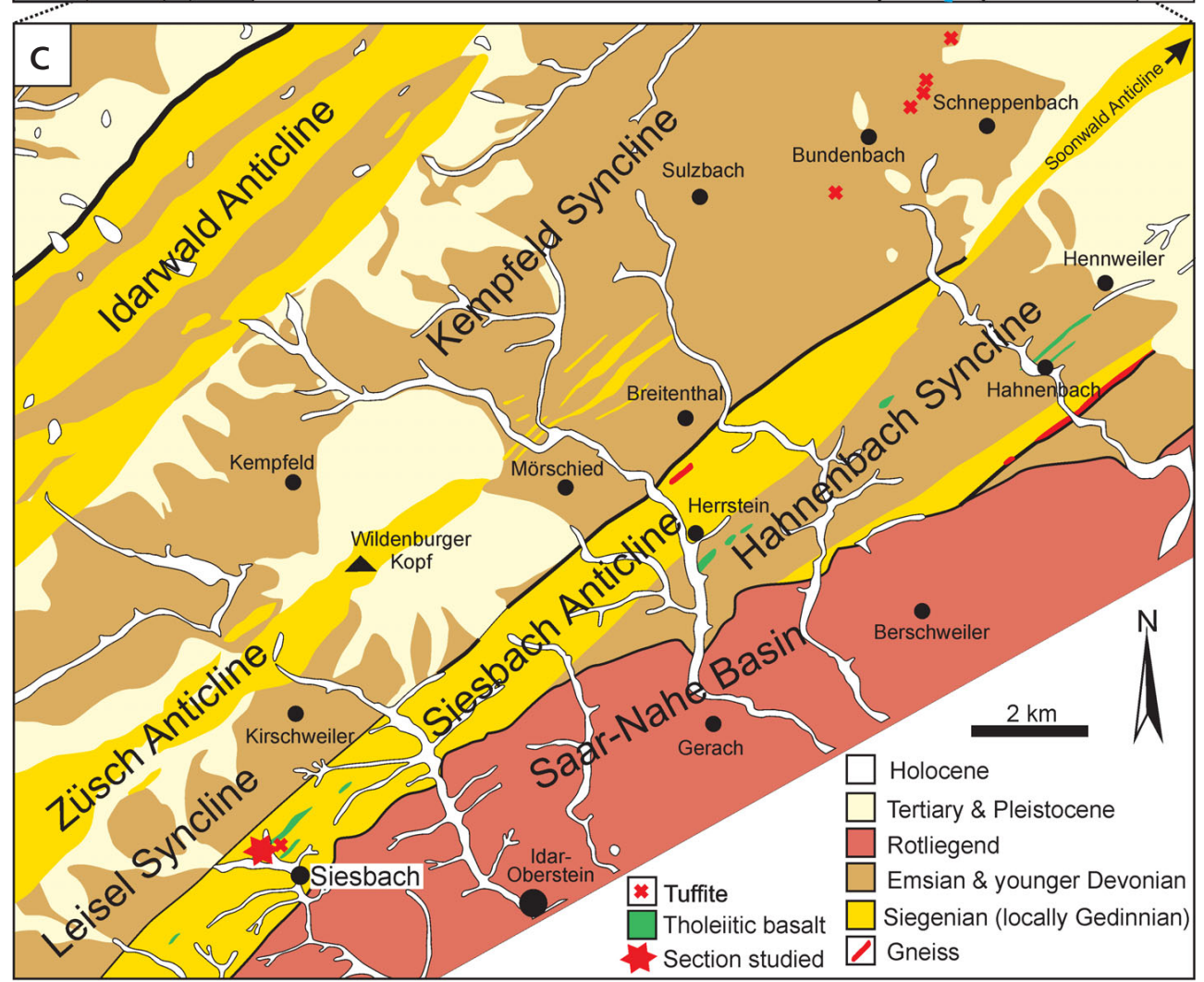

yielding a biostratigraphically relevant fauna (e.g. Oncken 1988, Knautz 1992, Wildberger 1992, Dittmar 1996). The famous fossiliferous sites in the Hunsrück at Bundenbach and Gemünden have now formally been assigned to the middle Kaub Formation which is of Lower Emsian age in the traditional German sense or Zlichovian of the Bohemian stratigraphy (Schindler et al. 2002; Kaufmann et al 2005; Mittmeyer 2008; De Baets et al. 2013a, b).

The lateral and vertical transition from the Taunusquarzit to the Hunsrückschiefer in the study area (SW 
Figure 2. Lithology of Siesbach section showing position of palynological samples (modified from Brocke et al. in Kneidl 2016).

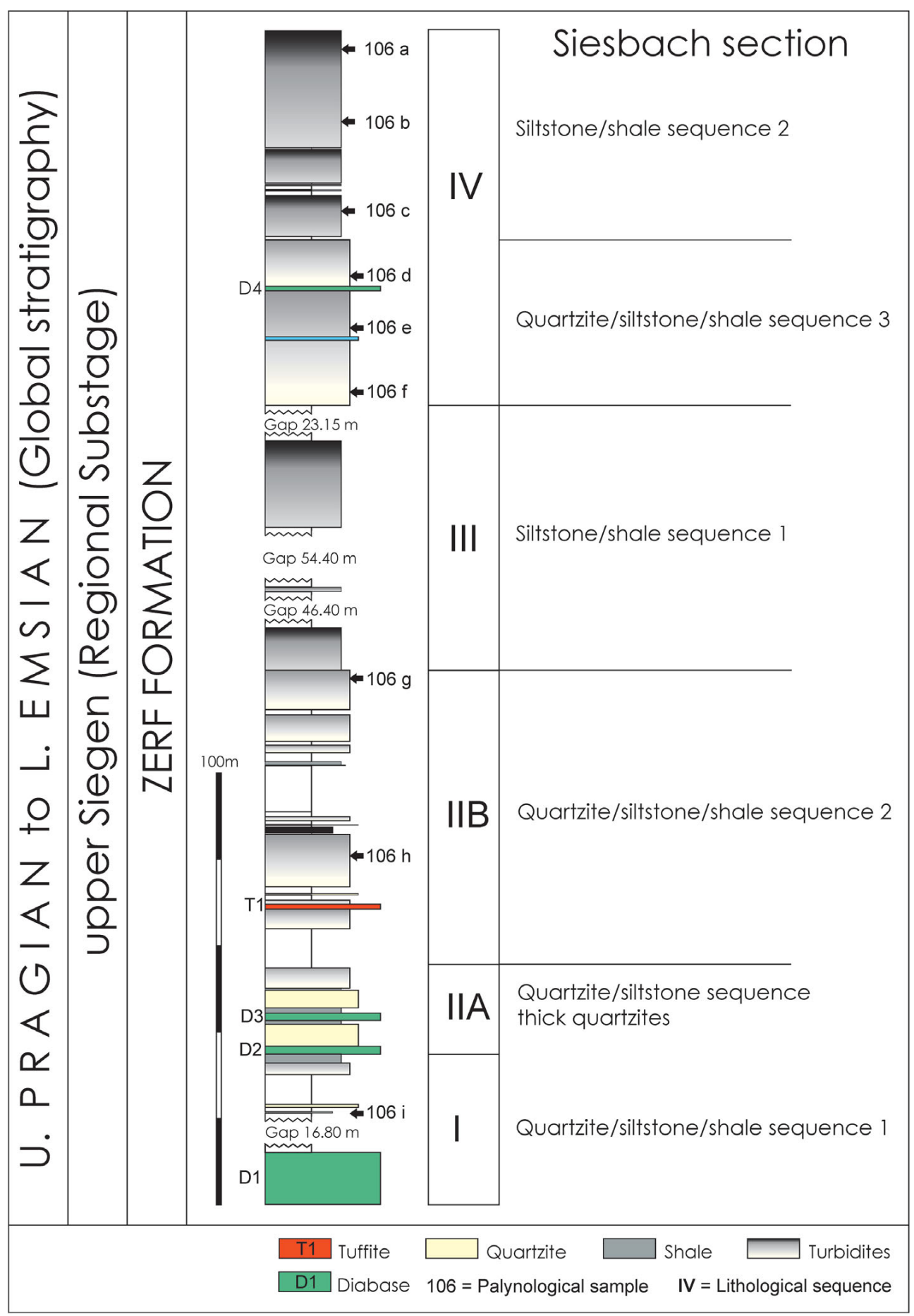

Hunsrück) is characterized by the increase of shale finally leading towards shales with subordinate intercalations of quartzitic layers (e.g. Knautz 1992, Meyer \& Nagel 2008). These mixed and transitional strata have been regionally assigned to two units, the Dhrontal Formation and the Zerf Formation, which are difficult to separate from each other. The Dhronthal Formation is characterized by a predominance of quartzites and includes a Siegenian fauna. There- fore, these beds are regarded as lateral equivalents of the Taunusquarzit (e.g. Nöring 1939, Stets 1962, Meyer \& Stets 1980). With a decrease of quartzitic intercalations, the sediments grade into the indistinctly delimited Zerf Formation, which yielded only scattered fossils indicating a transitional Siegen/Ems age in the traditional sense (e.g. Nöring 1939, Solle 1950, Wildberger 1992), which is equivalent to the Lower Emsian in the global sense. 
In the recent STG 2016 (Menning \& Hendrich 2016) the traditional regional Rhenish stages (Gedinne, Siegen, Ems) have been retained and correlated to the global stratigraphic scheme. We follow this view because of the continued widespread use of these regional stages and for comparison with much of the existing literature.

There are only few palynological studies of the Hunsrückschiefer. Following the first note by Holtz (1969) on the occurrence of spores in the Wispertal north of the Taunus, Karathanasopoulos (1974) studied samples from several roof-slate mines in the Hunsrück area. He described a rich microflora almost exclusively composed of spores and stated a maximum age of lower Ems but emphasized that the individual samples may represent different ages, possibly including Siegen ( Pragian). However, there is no reference to exact localities for the material. The presence of miospores has also been recorded in three sedimentologically and structurally oriented unpublished diploma theses carried out at the University of Göttingen (Ecke 1981, Hoffmann 1981, Ludewig 1981). A Gedinne $(\sim$ Lochkovian) to Siegen ( Pragian) age has been suggested for spores in the Hunsrïckschiefer facies of the southern Eifel by Gad (2005) which has later been separated as Wied Group from the Hunsrückschiefer Group by Elkholy \& Gad (2006). A few pyritized casts of spores and acritarchs have been figured from the Eschenbach Member of the Kaub Formation at Bundenbach by Tibbs et al. (2003).

For the present study, a recently exposed $370 \mathrm{~m}$ long forest road section at Siesbach, which includes sediments of the Hunsrückschiefer type, was measured in detail and sampled for palynology. No macrofossils have been discovered so far, but some samples yielded diverse associations of marine and non-marine palynomorphs. In spite of the high degree of thermal maturation, the studied material is surprisingly well preserved. Coalification rank of the late Siegen beds in the nearby Hahnenbach Valley ranges between 6 and $7 \% \mathrm{R}_{\max }$ (Ecke et al. 1985).

\section{Geological situation}

The Hunsrück area consists of a series of major synclinal and anticlinal structures (from NW to SE: Mosel-Syncline, Horath Anticline, Berglicht Syncline, Osburg-Hochwald Anticline, Thalfang Syncline, Idarwald Anticline, Hermeskeil-Kempfeld Syncline, Züsch Anticline, Leisel Syncline, Soonwald Anticline). Most of the anticlines are morphologically prominent due to the resistant quartzitic sandstones of the Taunusquarzit and its lateral equivalents (Nöring 1939, Stets 1962).

The area of the Siesbach section has been mapped as belonging to the Hunsrückschiefer of the Leisel Syncline (Leisel-Mulde of Nöring 1939). The tectonic situation is extremely complicated (Knautz 1992) and frequently obscured by the lack of outcrops and facies transitions. Therefore, existing maps are simplified with respect to detail (Dreyer et al. 1983, Dittrich et al. 2003). However, intense fieldwork by one of the authors (VK) recently revealed an additional anticlinal structure (Siesbach Anticline) to which the section belongs. Forming the southwestern continuation of the prominent Soonwald Anticline it intersects the former Leisel Syncline sensu Nöring (1939) and separates the Leisel Syncline sensu stricto in the northwest from the newly recognized Hahnenbach Syncline to the southeast (Fig. 1; Kneidl 2016).

The Siesbach section is composed of an alternation of quartzitic sandstones and siltstones with shales, however thicker quartzitic beds are only found near the base and shales are dominating towards the top. Magmatic intercalations are mainly present in the basal part (Fig. 2). The proportion of quartzites, siltstones and shales represents a transitional facies, which fits the description of the Zerf Formation (Spies \& Stets 2004; Landesamt für Geologie und Bergbau Rheinland Pfalz 2005) for the area; the separation of a similar transitional facies ("IdarbachSchichten") for the southwestern-most tectonic unit (which includes the Siesbach section) by Knautz (1992) appears arbitrary. Previously, there were no biostratigraphical data available for the Zerf Formation around the Siesbach section. However, it has been regarded as transitional between Siegen and Ems by Spies \& Stets (2004) according to regional lithostratigraphic and biostratigraphic data (Nöring 1939, Solle 1950, Stets 1962).

\section{Material and methods}

The studied material was collected from a $370 \mathrm{~m}$ long forest road section near Siesbach (Map sheet TK 6209 Idar-Oberstein 1:25.000 between coordinates R 2589280 / H 5911460 and R 2589180 / H 5911 780). The section has been measured and described in detail in the field while nine palynological samples were taken for the entire section with respect to lithology (Fig. 2).

The samples were prepared by applying standard

Figure 3. SEM images of cryptospores and simple miospores from the Siesbach section (Zerf Formation), Rheinisches Schiefergebirge, Germany. - A - alete monad cryptospore, Gneudnaspora divellomedia, sample Hs 106a. • B - alete monad cryptospore, Gneudnaspora divellomedia, sample Hs 106a. $\bullet \mathrm{C}$ - alete monad cryptospore?, sample Hs 106d. $\bullet$ D - small tetrad of cryptospore or retusoid miospores?, sample Hs $106 a$. E - cf. Acontotetras inconspicuis, sample Hs 106a. $\bullet \mathrm{F}-$ Tetrahedraletes medinensis, sample Hs $106 \mathrm{a} \cdot \bullet \mathrm{G}-$ cryptospore tetrad?, sample Hs $106 \mathrm{a}$. $\bullet \mathrm{H}-$ Retusotriletes sp. with 

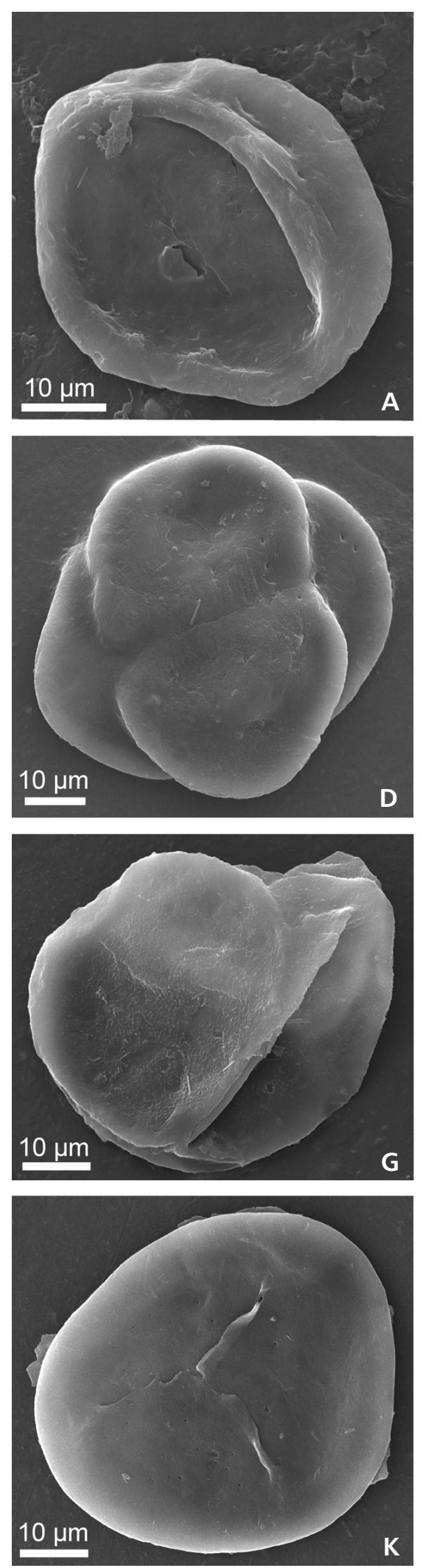

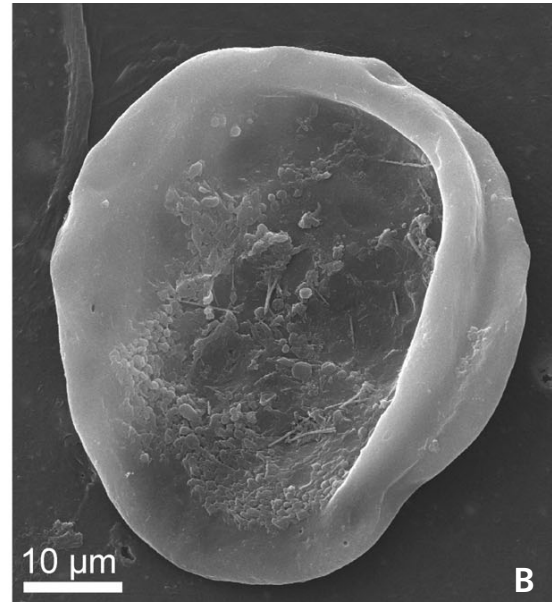

B
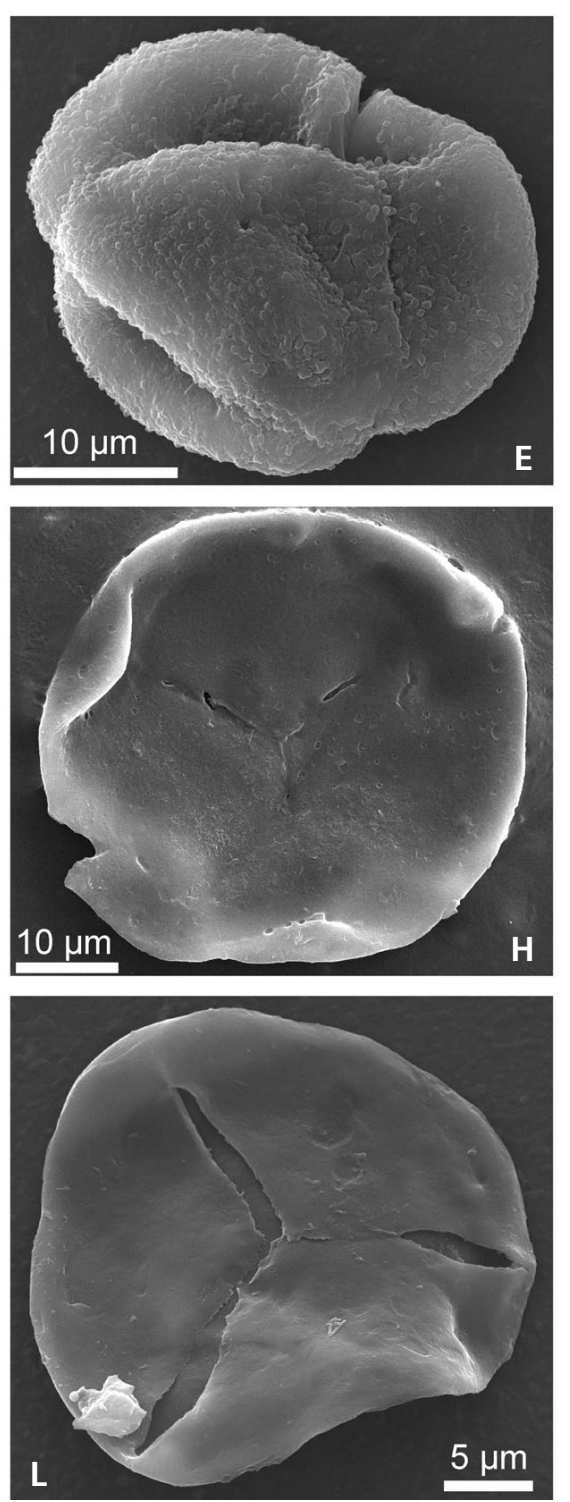
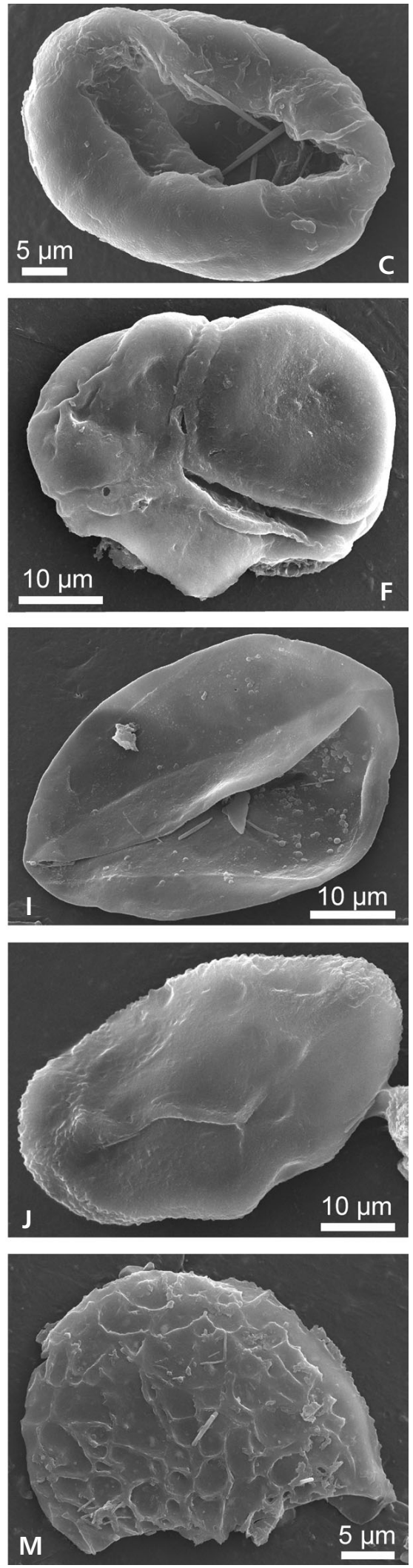

curvaturae imperfectae, sample Hs 106f. $\bullet$ I - large $(50 \mu \mathrm{m})$ specimen of ?Retusotriletes, sample 106a. • J - Apiculiretusispora brandtii, sample Hs $106 \mathrm{a}$. $\bullet \mathrm{K}$ - smooth trilete spore, Ambitisporites sp., sample Hs 106a. $\bullet$ L - smooth trilete spore, cf. Calamospora sp., sample Hs 106a. $\bullet$ M - Dictyotriletes cf. subgranifer, sample Hs 106a. 
palynological treatment with $\mathrm{HCl}$ and $\mathrm{HF}$ (e.g. Traverse 2007). Organic residues were sieved through a $10 \mu \mathrm{m}$ mesh sieve. Permanent strew mounts for conventional light and infrared microscopy (IR) were prepared with glycerol gelatine. For Scanning Electron Microscopy (SEM) studies putative palynomorphs were handpicked from uncovered spreads of the residue and, for better visibility, mounted on pieces of white plastic foil which was then fixed to aluminium stubs and coated with gold. All of the palynomorphs appeared barely transparent or completely opaque and in most cases did not show any diagnostic characters by conventional light microscopy. By applying IR they became slightly transparent to some degree, but even then details could not be recognized sufficiently. SEM finally revealed good preservation of morphological details in many specimens.

Karathanasopoulos (1974) in his study of classical Hunsrückschiefer sites, such as Gemünden and adjacent roof slate sites applied Schulze solution (Schulze 1855) as a strong oxidant to clear nearly opaque sporomorphs with remarkable success. We preferred non-destructive techniques such as IR and SEM to visualize diagnostic morphologic characters. Since transparency via IR was limited and restricted to thinner walled specimens, our identifications rely, therefore, primarily on SEM images. Because original diagnoses are traditionally based on transmitted light, our identifications are, consequently, subject to some uncertainties. On the other hand, minute surface features, which are much better resolved by SEM, are often considered taxonomically significant (Tappan \& Loeblich 1971).

Slides, stubs and residues are housed in the palynological collections of the Senckenberg Forschungsinstitut und Naturmuseum in Frankfurt am Main under inventory numbers PMP 658-660; 686; 692-695.

\section{Results}

\section{Cryptospores and smooth-walled obligate tetrads}

Cryptospores are common and represented by monads and tetrads, whereas dyads have not been observed, so far. Monads are mainly of the Gneudnaspora type, e.g. G. divellomedia (Chibrikova) Burgess \& Richardson, characterized by a thin hilum and a distinct equatorial crassitude (Fig. 3A, B). A possible cryptospore with ruptured proximal contact areas but lacking an equatorial crassitude is shown in Figure 3C. Several types of cryptospore tetrads have been encountered, e.g. Tetrahedraletes medinensis (Strother \& Traverse) Wellman \& Richardson (Fig. 3F). The partial separation of spores in the figured specimen is considered to be secondary due to extreme compaction rather than primary partial separation as diagnostic for $R i$ mosotetras Burgess. Tetrads not showing the diagnostic equatorial crassitude of cryptospores may simply be regarded as obligate tetrads of retusoid miospores (Fig. 3D, G). Tetrads with an apiculate to granular surface ornamentation (Fig. 3E) are very rare. Since they appear to have an equatorial crassitude, they are also considered to be cryptospores, similar to Acontotetras inconspicuis Richardson.

\section{Trilete spores}

Maceration residues of all samples include numerous rounded triangular opaque particles of various sizes. They can only be recognized as miospores in SEM studies, when the proximal side with trilete mark or distinctive sculpture at the outline are visible.

Smooth forms with and without curvaturae are numerous and represented by a wide range of sizes and preservation limiting closer taxonomic assignment. Those without apparent curvaturae and a thin, often folded or ruptured exine with a distinct but not prominent trilete mark may be referred to the genus Calamospora Schopf et al. (Fig. 3L). Other specimens with a rounded triangular outline and a more rigid possibly equatorially thickened exine can be assigned to the genus Ambitisporites Hoffmeister (Fig. 3K). Totally smooth retusoid forms with curvaturae fully extending to the equator and showing a circular outline may be assigned to Retusotriletes Naumova (e.g. Fig. 4A). Those with clearly smaller contact areas correspond well with Retusotriletes dittonensis Richardson \& Lister (Fig. 4B).

Spores referable to the genus Apiculiretusispora (Streel) Streel are rather common and diverse. The specimen shown in Figure 3J is somewhat distorted but with respect to the type of sculpture and all over size it falls within the broad range of $A$. brandtii Streel. The very subtle sculpture ("rough surface") of further specimens (e.g. Fig. 4C) suggests identification with A. plicata (Allen) Streel, however, comparison of our SEM micrograph to previous light micrographs are limited. Other specimens, e.g. Figure 4F, appear transitional between Apiculiretusispora and Dibolisporites Richardson. Nevertheless, they clearly differ from the late Emsian to Middle Devonian species of Dibolisporites by their small size and relatively low sculpture.

In the highly compressed and often distorted state of preservation, tripapillate taxa are not easily recognized except for Retusotriletes maculatus McGregor \& Camfield (Fig. 4D). The specimen shown in Figure 4K has the proximal papillae less clearly visible, but in all other morphological respects it closely corresponds to Streelispora newportensis (Chaloner \& Streel) Richardson \& Lister (compare with Richardson 1996, pl. 4, fig. 3; Richardson \& 

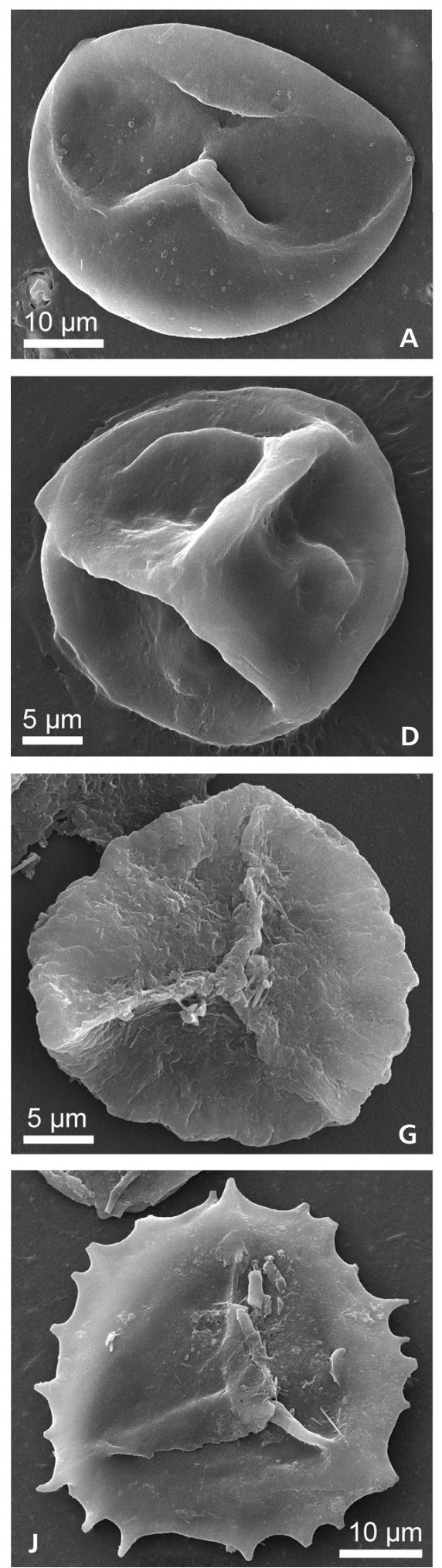
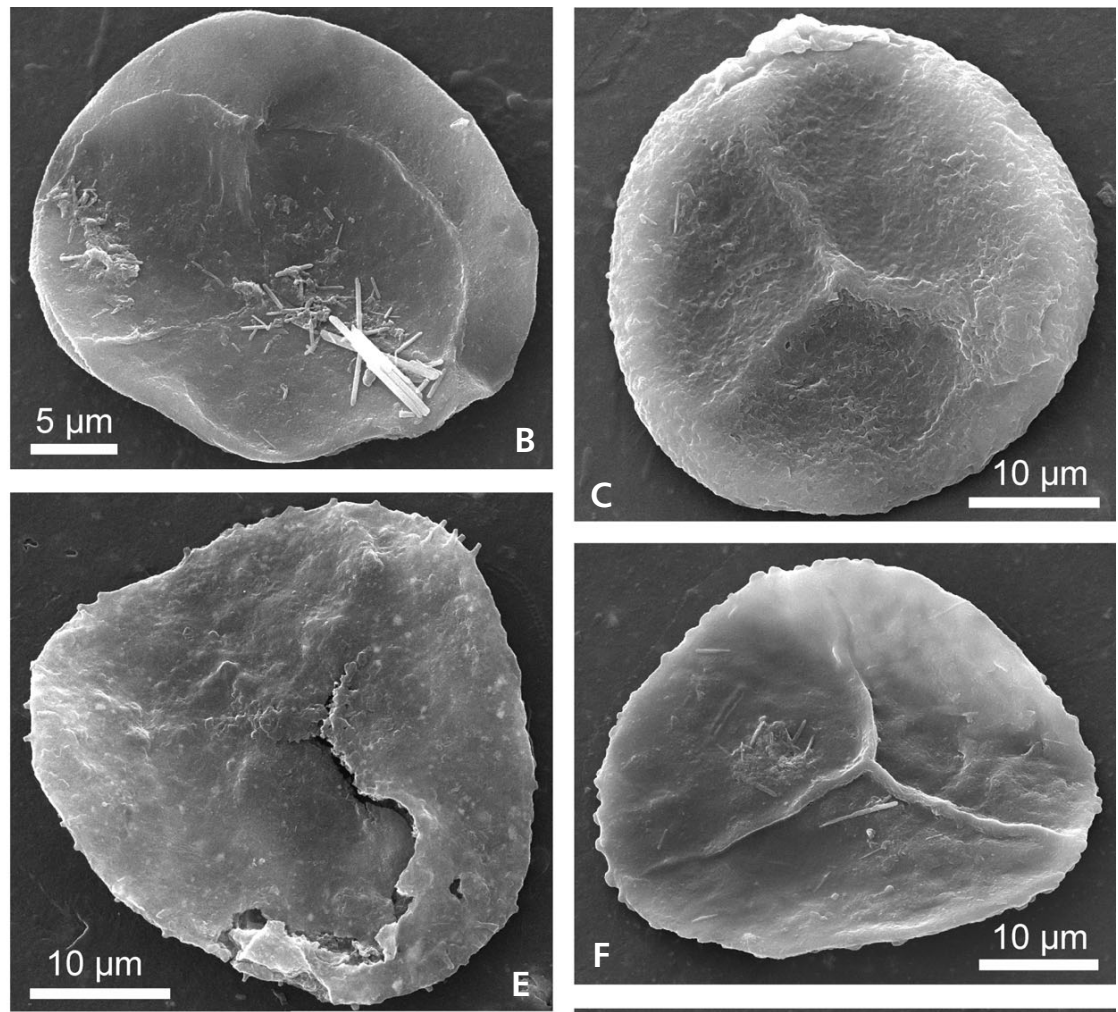

E
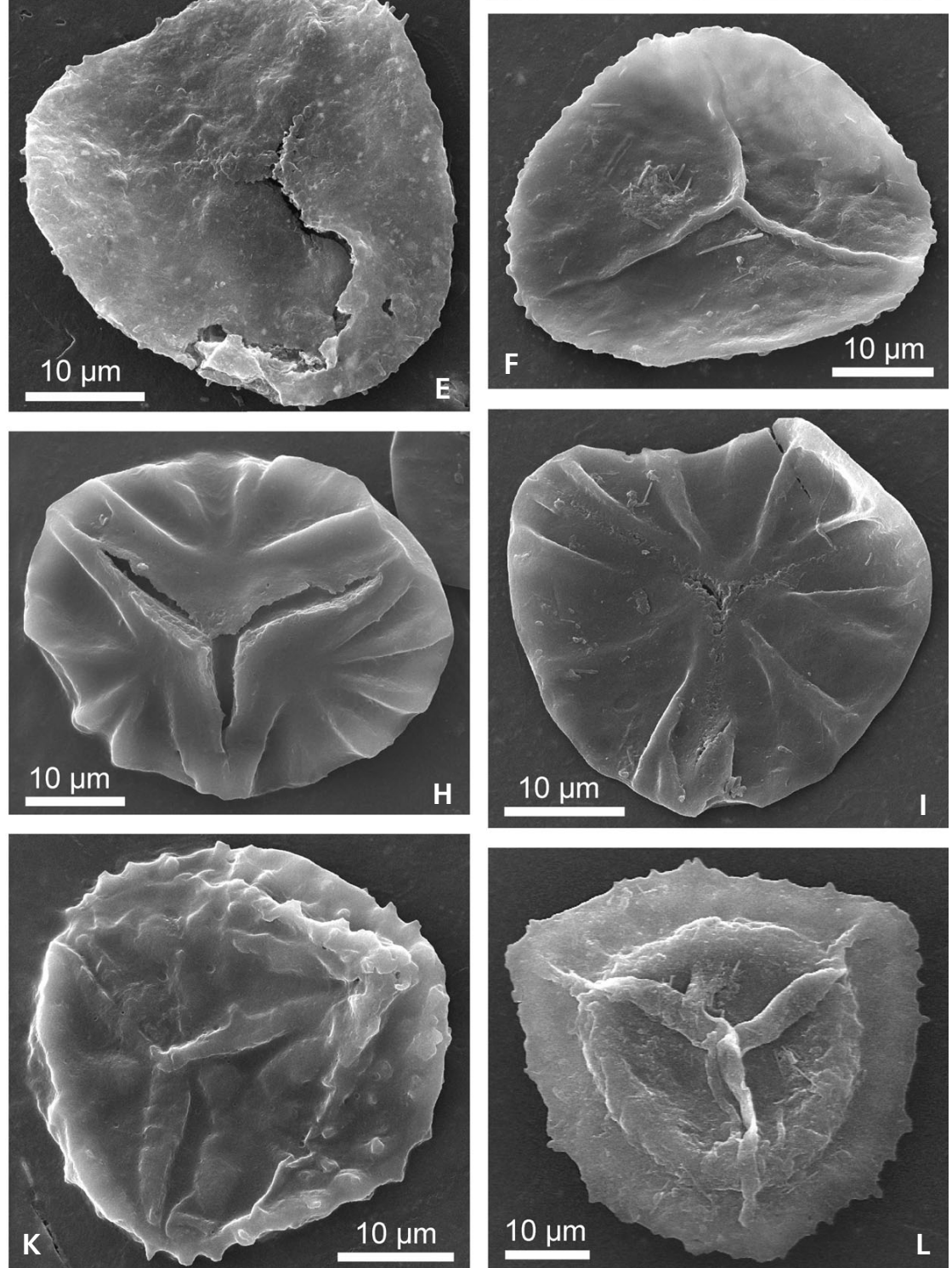

Figure 4. SEM images of miospores from the Siesbach section (Zerf Formation), Rheinisches Schiefergebirge, Germany. A - Retusotriletes rotundus, sample Hs 106g. • B - Retusotriletes dittonensis, sample Hs 106a. $\bullet$ C - Apiculiretusispora plicata, sample Hs 106d. $\bullet$ D - Retusotriletes maculatus, sample Hs 106a. $\bullet$ E - ?Aneurospora richardsonii, sample Hs 106h. $\bullet$ F - trilete spore indetermined, sample Hs 106d. $\bullet$ G - Cymbosporites sp., sample Hs 106d. $\bullet \mathrm{H}$ - Emphanisporites $\mathrm{cf}$. rotatus, sample Hs 106a. $\bullet$ I - Emphanisporites rotatus, sample Hs 106a. • J - Cymbosporites aff. echinatus, sample Hs 106d. $\bullet \mathrm{K}$ - Streelispora newportensis, sample Hs 106a. $\bullet \mathrm{L}$ - zonate trilete spore indet, sample Hs 106d. 
Lister 1969, pl. 41, fig. 6). Cymbosporites may be represented by several specimens showing more or less prominent spinose sculpture in the outline of proximal views and an equatorial thickening that may extend into a patina on the distal side (Fig. 4G, J). The specimen in Figure $4 \mathrm{~J}$ is somewhat similar to $C$. echinatus Richardson \& Lister because of a distinct equatorial thickening and prominent simple conical spines, which are visible along the spore outline.

The genus Emphanisporites McGregor is represented by several morphotypes. Most specimens of Emphanisporites are assignable to E. rotatus McGregor (Fig. 4I). The specimen designated as E. cf. rotatus on Figure $4 \mathrm{H}$ differs from E. rotatus in having broad laesurae accompanying the trilete mark and only few but strong radial ribs. In that, it is similar to Emphanizonosporites radiatus Schulz from the Klerf-Formation of the Eifel area, which, unlike our specimen, is larger and described as being cingulate (Schulz 1968). Several specimens with very faint proximal radial ribs resembling Emphanisporites multicostatus (sensu Rodriguez 1983) have also been observed. Rare specimens with incipient proximal ribs confined to the subequatorial region are comparable with E. protophanus Richardson \& Ioannides except for size (55 $\mu \mathrm{m}$ vs. $32-48 \mu \mathrm{m}$ in the original description).

A single, well-preserved specimen of a zonate spore with a distinct equatorial thickening around the central body and a prominent trilete mark can not presently be assigned to a distinct genus (Fig. 4L). It differs from Camptozonotriletes Staplin in showing small spines in the outer perimeter probably indicating a corresponding distal sculpture and from Breconisporites Richardson et al. by lacking a bizonate cingulum. The cincgulum of Densosporites (Berry) Butterworth et al. in Staplin \& Jansonius is generally more wedge-shaped and tapering in cross-section, while Samarisporites Richardson never develops a pronounced thickening around the central body. More specimens in various orientations are needed for precise identification.

Several distal surfaces of specimens with subcircular to subtriangular outline and a sculpture of loosely distributed slender coni have been encountered. They resemble those of Aneurospora richardsonii figured in Richardson et al. (2001, pl. 4, figs 1-3) also showing a slightly granular proximal surface. Unfortunately, in the highly compressed state of spores from Siesbach, no specimen is oriented to show both sides. However, a specimen from the lower part of the section (sample Hs 106h, Fig. 4E) showing slender spines in the outline and a granular surface around the trilete mark may represent a proximal view of this species.

\section{Phytoplankton}

The presence of a diverse phytoplankton association consisting of prasinophytes and acritarchs is new to the Hunsrückschiefer. In the sample Hs 106d, phytoplankton makes up more than half of the total assemblage. Other samples of the Siesbach section also include some phytoplankton but very subordinate to the land plant derived spores.

Large superficially smooth circular bodies (up to $80 \mu \mathrm{m}$ in diameter) with a small indentation on one side are interpreted as Tasmanites type prasinophyte phycomata (e.g. Fig. 5A). The lack of the typical pore canals in the wall may be attributed to the high thermal alteration. Sculptured prasinophytes are represented by Lophosphaeridium sp. (Fig. 5B) and by various species of Dictyotidium Eisenack differing in the mesh size of the reticulum. The specimen assigned to Dictyotidium cf. cavernulosum (Fig. 5C) is distinguished from D. cavernulosum Playford only by a slightly wider mesh of the reticulum.

A particularly interesting element is a species of Cymatiosphaera Wetzel with thick prominent crenulated crests, which, to our knowledge, has not been figured or described from the Devonian. Specimens morphologically similar to some degree have been described from the Ordovician of Estonia (Uutela \& Tynni 1991, pl. 9, figs 90-95). Several specimens of Cymatiosphaera in our material perhaps represent even more than a single species with individual species differing in the width of lumina and in the thickness of the crests (Fig. 5J-M).

Acritarch assemblages are dominated by polygonomorph and acanthomorph species. All specimens of Veryhachium trispinosum (Eisenack) Stockmans \& Willière are very small, thin-walled and fragile and, therefore, turned out to be unsuitable for SEM preparations, but could be figured as IR images from permanent strew mounts (Fig. 6A-C). Other species of Veryhachium Deunff have not been observed. All forms with a more or less polygonal vesicle and long spines with flaring bases are included within the genus Micrhystridium Deflandre, which traditionally has a wide circumscription. There is considerable variation in the number and length of spines in the specimens from the Siesbach section (Fig. 5G; Fig. 6D, E). The figured specimens are tentatively assigned to M. stellatum Deflandre. Similar spiny forms with

Figure 5. SEM images of prasinophytes and acritarchs from the Siesbach section (Zerf Formation), Rheinisches Schiefergebirge, Germany. - A - Tasmanites sp., sample Hs 106d. • B - Lophosphaeridium sp., sample Hs 106d. • C - Dictyotidium cf. cavernulosum, sample Hs 106d. - D - Gorgonisphaeridium sp., sample Hs 106d.• E ?Gorgonisphaeridium sp., sample Hs 106d. • F - Gorgonisphaeridium sp., sample Hs 106d. 

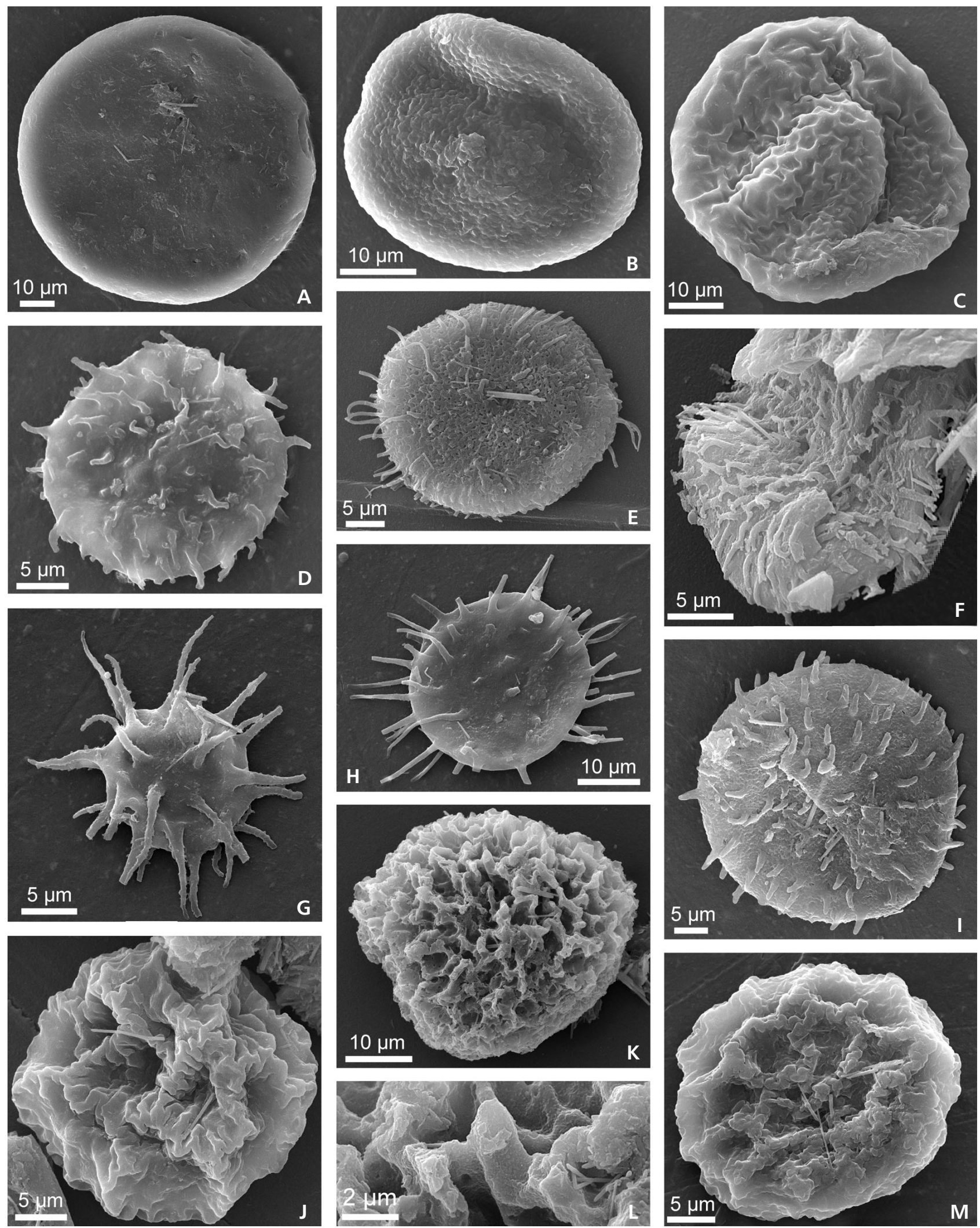

- G - Micrhystridium sp., sample Hs 106d. • H - Baltisphaeridium sp., sample Hs 106d. • I - Gorgonisphaeridium sp., sample Hs $106 \mathrm{~d}$.

- J - Cymatiosphaera sp.1, sample Hs 106d. • K - Cymatiosphaera sp.2, sample Hs 106d. • L - same specimen as in K, detail of sculpture.

- M - Cymatiosphaera sp.1, sample Hs 106d. 
a distinctly spherical vesicle and an angular juncture with the spines may be related to the genus Baltisphaeridium Eisenack, when broken spines proved to be hollow (Fig. 5H).

Multiplicisphaeridium sp. with short stout appendages (Fig. 5F) is similar to M. albanegum Cramer et al., but broken specimens with long delicately branched appendages ( $M$. ramusculosum type) have occasionally been observed.

Several specimens have been recorded with relatively short spines, which are broadened or bifurcate to multifurcate at the tip (Fig. 5D, I). Variants of this type may represent more than one species included in the genus Gorgonisphaeridium Staplin et al. The specimen depicted in Figure 5E, for instance, is characterized by a distinct foveolate to finely reticulate sculpture on the central body and is tentatively assigned to Gorgonisphaeridium. Specimens with spherical to subspherical, relatively thickwalled vesicle with dense ornamention of short, irregularly shaped tubercles are attributed to the genus Lophosphaeridium (Timofeev) Lister (Fig. 5B).

In addition, two specimens of scolecodonts (not figured) have been recorded in sample 106a.

\section{Discussion}

Being located at the southeastern limb of the Siesbach Anticline the Siesbach section is, thus far, the most southern site in the Hunsrück area from which palynomorphs have been isolated and determined (Appendix Table 1). Broad outcrops of sediments of the Hunsrückschiefer type (here Zerf Formation) in this region have, thus far, not provided any faunal evidence for biostratigraphic correlation with the Hunsrückschiefer of the classical sites, which has recently been dated as early Emsian (Middle Kaub Formation) by ammonoids (De Baets et al. 2013b). The recent discovery of palynomorph assemblages at Siesbach now holds promises for closer assessment of age relations among sediments of the Hunsrückschiefer type and in particular to those of the type area at Bundenbach and Gemünden.

Palynomorphs have been isolated from most of the sampled levels in the Siesbach section with decreasing abundance, diversity and quality of preservation down-section.
Terrestrial miospores are best represented in the sample Hs 106a. The sample Hs 106d stands out, since it includes a rather diverse phytoplankton assemblage along with miospores, while all other samples have yielded only rare specimens of Veryhachium. Aside from this, vertical changes in assemblage composition are difficult to assess because of the paucity of spores in the lower part of the section.

Figure 8 shows the known stratigraphic ranges of some of the more reliably determined spore taxa. Most of them have a fairly wide range through much of the Lower Devonian. In the zonation scheme of Richardson \& McGregor (1986) for the Silurian and Devonian of the Old Red Continent and adjacent regions, the Siesbach assemblages do not have a close counterpart, but correspond best with the Emphanisporites micrornatus-Streelispora newportensis Assemblage Zone designated as Lochkovian ( Gedinnian, except earliest Gedinnian) in age. However, the upper part of this zone is not well documented and spore zones of Richardson and McGregor (1986) are generally set up based on first appearances. Except for Streelispora newportensis none of the nominal species for the concurrent range (Oppel zones) and interval zones in the scheme of Streel et al. (1987) has yet been identified in the Siesbach section.

The closest age constraint is provided by Retusotriletes dittonensis and Streelispora newportensis. According to Steemans (1989) both species first appear in the "Gedinnian" ( Lochkovian) developing their acme in the "Gedinnian" and "Siegenian" but extend into the early Emsian according to Moreau-Benoit \& Boureau (1989). Palynological analysis of marine sections from the northern Eifel region, which are well dated by marine faunas (Fuchs 1974), has shown that Emsian spore assemblages are much more diverse, including more complex species of Emphanisporites, e.g. E. annulatus and E. foveolatus (Riegel \& Karathanasopoulos 1982). Both species are missing in the studied interval. The very characteristic distal surfaces of these two species would be diagnostic for species identification, even when the proximal radial ribs cannot be seen in SEM micrographs. In addition, Verruciretusispora dubia (Eisenack) Richardson \& Rasul and the first typical species of Dibolisporites, e.g. D. echinaceus (Eisenack) Richardson emend. McGregor, are missing from sections of the Herdorf Group (Siegen) of

Figure 6. Transmitted light (TM) and infrared (IR) photographs of acritarchs and miospores from the Siesbach section (Zerf Formation), Rheinisches Schiefergebirge, Germany. Indicated are sample (Siesbach P), slide number (-1), England Finder (E.F.) coordinates, and collection identification number (PMP). • A - Veryhachium trispinosum, sample Siesbach P 106d-1, E.F. X 43-4, PMP 686. • B - Veryhachium trispinosum, sample Siesbach P 106d-3, E.F. A 54-3, PMP 686. • C - Veryhachium trispinosum, sample Siesbach P 106d-4, E.F. L 59-1, PMP 686. • D - Micrhystridium stellatum, sample Siesbach P 106d-1, E.F. X 43-4, PMP 686. • E-Micrhystridium ?stellatum, sample Siesbach P 106d-3, E.F. J 43-3, PMP 686. • F - Multiplicisphaeridium sp., sample Siesbach P 106d-1, E.F. W 34-3, PMP 686. • G - Multiplicisphaeridium sp., sample Siesbach P 106d-4, E.F. E 43-1, PMP 686. - H - Apiculiretusispora sp., sample Siesbach P 106d-3, E.F. Q 63-3, PMP 686. • I - cf. Streelispora sp. B sensu Steemans 1989 (pl. 46 , 12), sample Siesbach P 106a-3, E.F. H 61-4, PMP 658. • J - Emphanisporites cf. protophanus, sample Siesbach P 106a-3, E.F. X37-4, PMP 658. • K - spore tetrad, 


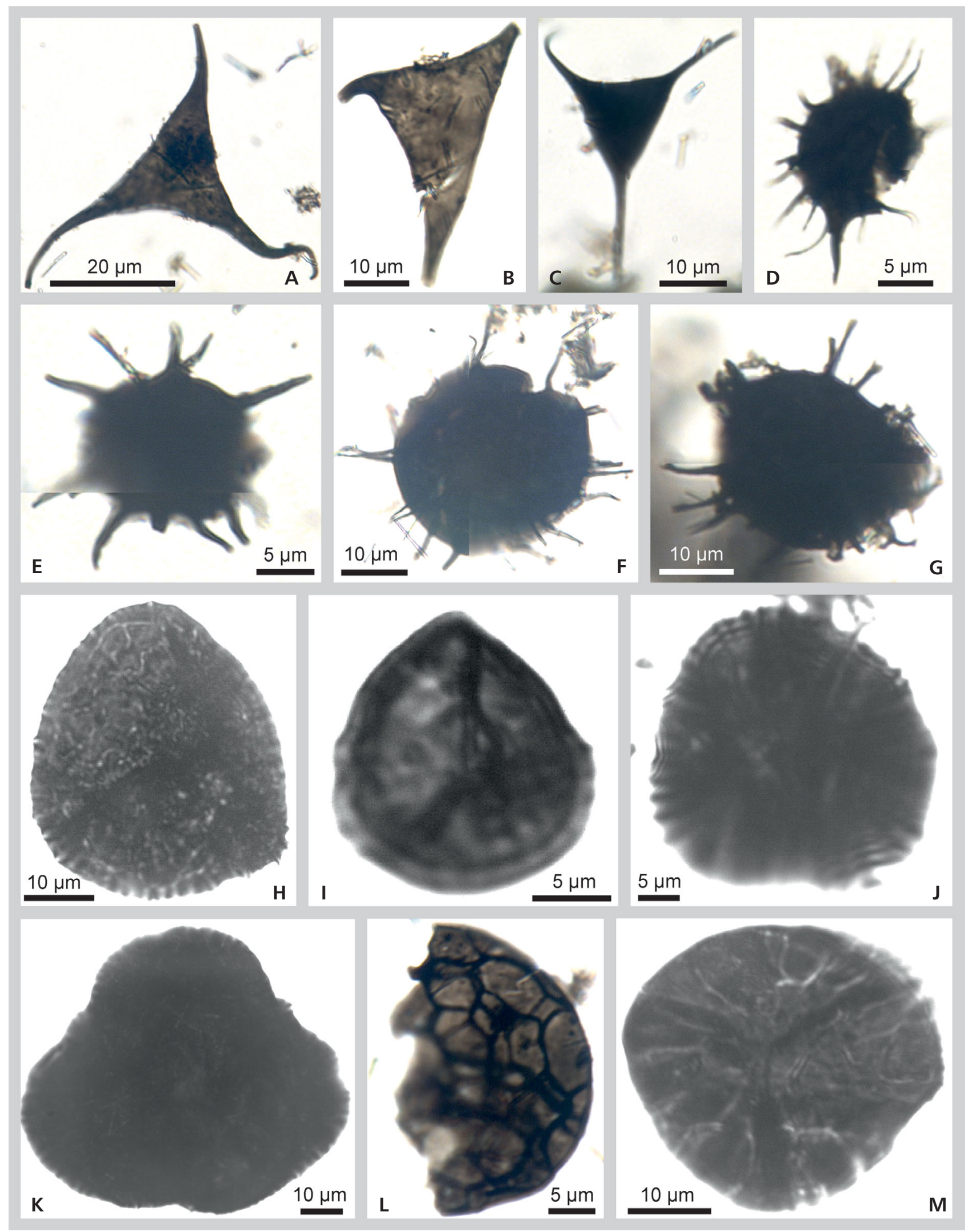

?Retusotriletes, sample Siesbach P 106d-3, E.F. N 57, PMP 686. - L - Dictyotriletes sp., sample Siesbach P 106d-1, E.F. P 47-1, PMP 686. - - M Emphanisporites rotatus, sample Siesbach P 106a-4, E.F. Y 40-2, PMP 658. 


\begin{tabular}{|c|c|c|c|c|c|c|c|c|c|c|c|c|}
\hline$\frac{\frac{E}{D}}{\stackrel{D}{\infty}}$ & $\begin{array}{l}\text { Global } \\
\text { Stage }\end{array}$ & $\begin{array}{c}\text { Regional } \\
\text { Stage }\end{array}$ & 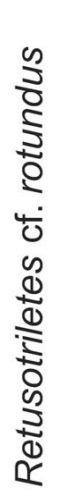 & 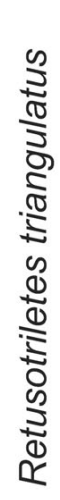 & 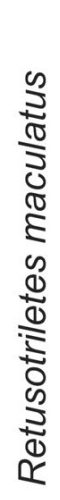 & 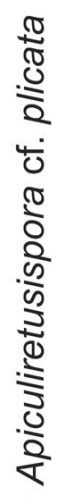 & 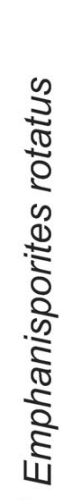 & 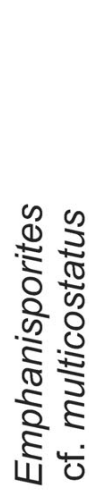 & 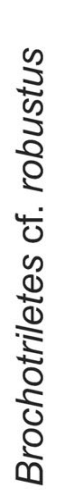 & 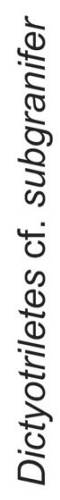 & 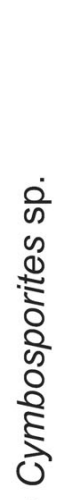 & 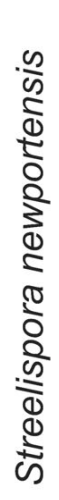 \\
\hline \multirow{4}{*}{ 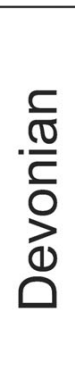 } & Eifelian & Eifel & $\uparrow$ & 个 & & 4 & 4 & & & & 4 & \\
\hline & Emsian & Ems & & & & & & & & & & \\
\hline & Pragian & Siegen & & & & & & & & & & \\
\hline & Lochkovian & Gedinne & & & & & & & & $\vdots$ & & \\
\hline \multirow{3}{*}{$\begin{array}{l}\frac{}{\sqrt{0}} \\
\frac{\overline{2}}{\bar{D}} \\
\overline{\bar{c}}\end{array}$} & & & & & & & & & & & & \\
\hline & $\begin{array}{c}\text { Ludfordian } \\
\text { Gorstian }\end{array}$ & & & & & & | & & & & & \\
\hline & Homerian & & & & & & & & & & & \\
\hline
\end{tabular}

Figure 7. Range chart of selected miospore taxa.

the Eifel area as well as from Siesbach. In addition, the Silurian to Lochkovian ( Gedinne) species Emphanisporites protophanus has also been recorded in the Kürrenberg Formation (Herdorf Group) of the Eifel area (Riegel \& Karathanasopoulos 1982). Apparently, last occurrences of Lower Devonian spore taxa are not very well defined. On the other hand, stratigraphic marker taxa on which Gad (2005) based a "Gedinnian" ( Lochkovian) age for sediments of the Hunsrückschiefer type (Mayen Formation) of the Eifel/Westerwald region have not been found at Siesbach. Consequently, in the absence of taxa restricted either to the Silurian to Lochkovian on one side or Emsian on the other side; a Pragian to lowermost Emsian (most probably late Siegen) age can be assigned to the Siesbach section. This would also correspond quite well with the lithologic transition between the Taunusquarzit and the Hunsrïckschiefer as well as the tectonic position on the southeastern limb of the Siesbach Anticline with Taunusquarzit in its core.

Nevertheless, in view of the common occurrence of cryptospores and miospores with a late Silurian to earliest Devonian acme as well as the possible correlation with the E. micrornatus-S. newportensis Assemblage Zone, re- working of part of the Siesbach assemblages from an older source cannot be excluded. This consideration is in accordance with locally included turbiditic sequences in the Siesbach section (personal observation, VK). However, the variegated shales and sandstones of the adjacent Lochkovian (Gedinne) outcrops (Bunte Schiefer/Züsch Schiefer) and the Pragian (early Siegen) Hermeskeil Formation have never produced any plant remains and are, therefore, unlikely sources for the Siesbach miospores.

The new evidence of a rather diverse marine phytoplankton assemblage along with rare scolecodonts in the upper part of the Siesbach section is quite remarkable, since marine palynomorphs (e.g. acritarchs and prasinophytes) have been observed very rarely in the Hunsrückschiefer thus far (Karathanasopoulos 1974, Tibbs et al. 2003). This indicates, at least, varying degrees of marine influence at Siesbach, which is possibly due to a general deepening trend from the late Pragian to the early Emsian in the Rheinisches Schiefergebrige (Jansen 2016). This also contrasts to the Hunsrückschiefer Lagerstätte and other Hunsrückschiefer sites where the near lack of phytoplankton, especially acritarchs, suggests water column stratification. 
Figure 8. Stratigrapy and facies relation of the Hunsrückschiefer Group and sediments of the Hunsrückschiefer type in the central and southwestern Hunsrück; in part adapted from Stets \& Schäfer (2011).

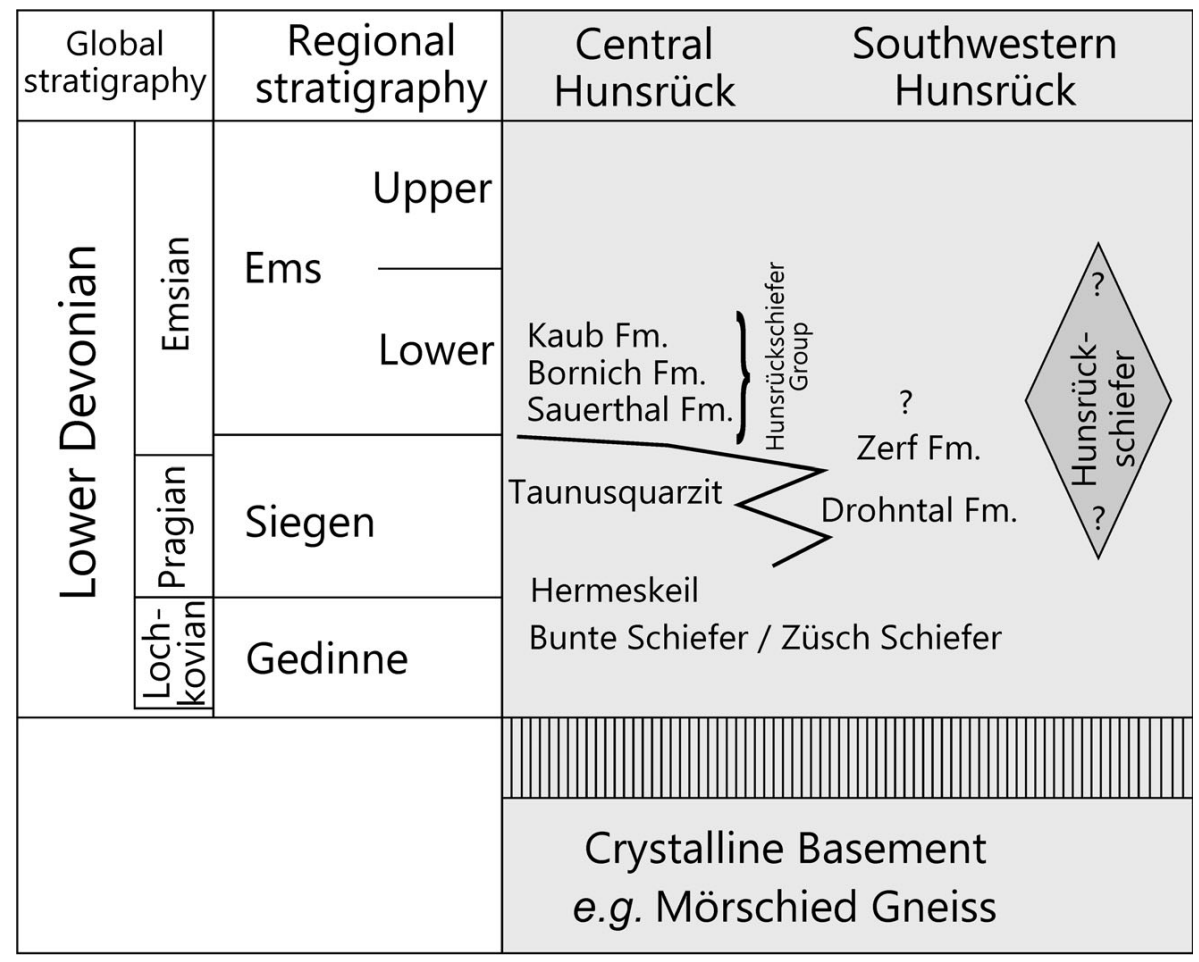

\section{Conclusions}

Despite the complex tectonic deformation and a high thermal alteration, surprisingly well preserved and diverse palynomorph assemblages (cryptospores, miospores, prasinophytes, acritarchs) have been isolated from sediments of the Hunsrückschiefer type in the southwestern Hunsrück area near Siesbach. This allows new insights into age relations between the Hunsrückschiefer Lagerstätte and its facies equivalents and reveals significant variations in the environment of deposition.

At this stage of our study, a Siegen (late Pragian to earliest Emsian) age seems to be most likely for the Hunsrückschiefer type as exposed in the Siesbach section (Zerf Formation) since all species listed range through the Siegen while typical guide species for higher parts of the lower Emsian in the well studied Eifel area, such as Emphanisporites annulatus (Singhofen beds), E. foveolatus and Verruciretusispora dubia (Klerf Formation) are missing (Riegel \& Karathanasopoulos 1982). This indicates that the Zerf Formation exposed in the Siesbach section is older than the Hunsrückschiefer roof slates of the middle Kaub Formation from the classical sites near Bundenbach (Rhaunen) and Gemünden, where these typically late lower Emsian index species have been recorded (Karathanasopoulos 1974). It postdates, however, the sediments of the Hunsrückschiefer type sediments from the Eifel/Westerwald area (Wied Group; Elkholy \& Gad 2006).

The discovery of a diverse acritarch assemblage in parts of the section suggests that marine influence was in- termittently more pronounced in the Zerf Formation of the southwestern Hunsrück than at the classical sites of the Hunsrückschiefer in which phytoplankton has very rarely been observed thus far (Tibbs et al. 2003; personal observations WR). This is in sharp contrast to the presence of a rich marine fauna there and its complete lack in the Siesbach section, possibly due to variable salinities in the photic zone.

In general, our study serves as an example that palynology can be applied successfully by means of SEM in stratigraphic correlation and environmental interpretation of otherwise unfossiliferous strata even when they are highly tectonized and thermally altered. However, in order to confirm SEM-based identifications of palynomorph taxa with traditional diagnoses based on transmitted light microscopy, comparisons by both techniques from suitable material would be useful.

\section{Acknowledgements}

Sincere thanks are expressed to the technical assistants of the Senckenberg Research Institute Frankfurt, Jutta OelkersSchaefer and Gunnar Riedel, who processed the palynological samples. We are grateful to Oldřich Fatka (Charles University, Prague) for helpful comments to an early version of the manuscript, and to the reviewers Philippe Steemans (University of Liège) and Jiří Bek (Institute of Geology, Academy of Sciences, Prague) for critical and useful remarks, which helped to improve the paper. 


\section{References}

Anderle, H.J. 2008. Südtaunus. In Deutsche Stratigraphische Kommission (ed.) Stratigraphie von Deutschland VIII. Devon. Schriftenreihe der Deutschen Gesellschaft für Geowissenschaften 52, 118-130.

Bartels, C. \& Brassel, G. 1990. Fossilien im Hunsrückschiefer. 232 pp. Museum Idar-Oberstein, Idar-Oberstein.

Bartels, C., Briggs, D.E.G. \& Brassel, G. 1998. The Fossils of the Hunsrück Slate: Marine Life in the Devonian. 309 pp. Cambridge University Press, Cambridge.

De Baets, K., Goolaerts, S., Jansen, U., Rietbergen, T. \& KLuG, C. 2013a. The first record of Early Devonian ammonoids from Belgium and their stratigraphic significance. Geologica Belgica 16(3), 148-156.

De Baets, K., Klug, C., Korn, D., Bartels, C. \& Poschmann, M. 2013b. Emsian Ammonoidea and the age of the Hunsrück Slate (Rhenish Mountains, Western Germany). Palaeontographica A 299, 1-113. DOI 10.1127/pala/299/2013/1

DitTMAR, U. 1996. Profilbilanzierung und Verformungsanalyse im südwestlichen Rheinischen Schiefergebirge. Zur Konfiguration, Deformation und Entwicklungsgeschichte eines passiven varistischen Kontinentalrandes. Beringeria 17, $1-346$.

Dittrich, D., Franke, W.R., Gad, J., Haneke, J., Requadt, H., SCHÄFER, P. \& WeIDENFELLER, M. 2003. Geologische Übersichtskarte von Rheinland-Pfalz 1:300.000. Landesamt für Geologie und Bergbau Rheinland-Pfalz, Mainz.

Dreyer, G., Franke, W.R. \& Stapf, K.R.G. 1983. Geologische Karte des Saar-Nahe-Berglandes und seiner Randgebiete 1:100.000. Landesamt für Geologie und Bergbau Rheinland-Pfalz, Mainz.

ECKE, H.H. 1981. Geologische Untersuchungen am Nordostende des Idarwaldes (Rheinische Schiefergebirge/Hunsrück). 151 pp. Master thesis, University of Göttingen.

Ecke, H.H., Hoffmann, M., Ludewig, B. \& Riegel, W. 1985. Ein Inkohlungsprofil durch den südlichen Hunsrück (südwestliches Rheinisches Schiefergebirge). Neues Jahrbuch für Geologie und Paläontologie, Monatshefte 1985(7), 395-410.

Elkholy, H. \& GAD, J. 2006. Die Wied-Gruppe (vormals Hunsrückschiefer): Eine neue lithostratigraphische Einheit am Nordrand der Moselmulde Untersuchungen zu ihrer faziellen und stratigraphischen Einordnung. Mainzer geowissenschaftliche Mitteilungen 34, 49-72.

Engels, B. 1956. Über die Fazies des Hunsrückschiefers. Geologische Rundschau 45(1), 143-150. DOI 10.1007/BF01792759

Fuchs, A. 1907. Die Stratigraphie des Hunsrückschiefers und der Untercoblenzschichten am Mittelrhein nebst einer Übersicht über die spezielle Gliederung des Unterdevons mittelrheinischer Facies und die Faciesgebiete innerhalb des rheinischen Unterdevons. Zeitschrift der Deutschen Geologischen Gesellschaft 59(1907), 96-119.

Fuchs, G. 1974. Das Unterdevon am Ostrand der Eifeler Nordsüd-Zone. Beiträge zur naturkundlichen Forschung Südwestdeutschlands, Beiheft 2, 3-163.
GAD, J. 2005. Miosporen aus dem Hunsrückschiefer des Westerwaldes (Rheinisches Schiefergebirge, Unterdevon) und die stratigraphische Stellung der Mayen-Formation. Mainzer geowissenschaftliche Mitteilungen 33, 167-218.

GAD, J. 2006. Was ist eigentlich Hunsrückschiefer? Jahresberichte und Mitteilungen des Oberrheinischen Geologischen Vereines, Neue Folge 88, 53-65.

Hoffmann, M., 1981. Geologische Untersuchungen im südlichen Hahnenbachtal zwischen dem Lützelsoon und Kirn (Hunsrück/Rheinisches Schiefergebirge). 156 pp. Master thesis, University of Göttingen.

Holtz, S. 1969. Beiträge zur Sedimentation und Fossilführung des Hunsrückschiefers 25. Sporen im Hunsrückschiefer des Wisper-Tales (Rheingaukreis, Hessen). Notizblatt des Hessischen Landesamtes für Bodenforschung zu Wiesbaden 97, 389-390.

JAHNKE, H. \& BARTELs, C. 2000. Der Hunsrückschiefer und seine Fossilien, Unter-Devon, 36-44. In Pinna, G. \& MeIschner, D (eds) Europäische Fossillagerstätten. Springer Verlag Berlin, Heidelberg.

JANSEN, U. 2016. Brachiopod faunas, facies and bisostratigraphy of the Pridolian to lower Eifelian succession in the Rhenish Massif (Rheinisches Schiefergebirge, Germany), 45-122. In Becker, R.T., Königshof, P. \& BRETt, C.E. (eds) Devonian Climate, Sea Level and Evolutionary Events. Geological Society of London, Special Publications, 423. DOI 10.144/SP423.11

Karathanasopoulos, S. 1974. Sporen aus den schwach metamorphen unterdevonischen Dachschiefern des Hunsrücks (Rheinland, Deutschland). 80 pp. Ph.D. thesis, University of Mainz.

Kaufmann, B., Trapp, E., Mezger, K. \& Weddige, K. 2005. Two new Emsian (Early Devonian) U-Pb zircon ages from volcanic rocks of the Rhenish Massif (Germany; implications for the Devonian time scale. Journal of the Geological Society, London 162(2), 363-371. DOI 10.1144/0016-764904-012

KnAutZ, D. 1992. Beckenentwicklung und strukturelle Ausgestaltung des südlichen Rheinischen Troges am Beispiel von "Züscher Sattel" und "Leiseler Mulde" (SW-Hunsrück, Rheinisches Schiefergebirge). Bonner Geowissenschaftliche Schriften 5, 1-234.

KNEIDL, V. 2011. Hunsrück, Insel der Tropen. 144 pp. Streifzüge durch die Erdgeschichte. Edition Goldschneck. Quelle \& Meyer Verlag, Leipzig.

KNEIDL, V. 2016. Der unterdevonische Bundenbach-"Canyon”. 150 Jahre Hunsrückschiefer-Forschung. Fossilien 33(2), 52-57.

Landesamt Für Geologie und Bergbau Rheinland-Pfalz 2005. Geologie von Rheinland Pfalz. 400 pp. Schweizerbart Science Publishers, Stuttgart.

LuDEWIG, B. 1981. Geologische Untersuchungen im Hahnenbachtal vom Lützelsoon bis Bundenbach im Hunsrück (Rheinisches Schiefergebirge). 153 pp. Master thesis, University of Göttingen.

Menning, M. \& Hendrich, A. (eds) 2016. Stratigraphic Table of Germany 2016. German Stratigraphic Commission, Potsdam.

MeYer, D.E. \& NAgel, J. 2008. Südhunsrück-Trog. In Weddige, 
C. (ed.) Stratigraphie von Deutschland VIII. Devon. Schriftenreihe der Deutschen Gesellschaft für Geowissenschaften 52, 131-138.

Meyer, W. \& Stets, J. 1980. Zur Paläogeographie von Unterund Mitteldevon im westlichen und zentralen Rheinischen Schiefergebirge. Zeitschrift der Deutschen geologischen Gesellschaft 131, 725-751.

Meyer, W. \& Stets, J. 1996. Das Rheintal zwischen Bingen und Bonn. Sammlung geologischer Führer 89 (Borntraeger), $1-386$.

MitTmeYer, H.G. 1980. Zur Geologie des Hunsrückschiefers. Natur und Museum 110, 148-155.

MittmeYer, H.G. 2008. Unterdevon der Mittelrheinischen und Eifeler Typ-Gebiete (Teile von Eifel, Westerwald, Hunsrück und Taunus, 139-203. In Weddige, C. (ed.) Stratigraphie von Deutschland VIII. Devon. Schriftenreihe der Deutschen Gesellschaft für Geowissenschaften 52.

Moreau-Benoit, A \& Boureau, E. 1989. New palynostratigraphical data on the Armorican Lower Devonian. Comptes Rendus de l'Académie des Sciences Série II 308, 1299-1306.

NöRING, F.K. 1939. Das Unterdevon im westlichen Hunsrück. Abhandlungen der Preußischen Geologischen Landesanstalt, Neue Folge 192, 1-96.

OnCKen, O. 1988. Geometrie und Kinematik der Taunuskammüberschiebung Beitrag zur Diskussion des Deckenproblems im südlichen Schiefergebirge. Geologische Rundschau 77(2), 551-575. DOI 10.1007/BF01832398

Richardson, J.B. 1996. Lower and middle Palaeozoic records of terrestrial palynomorphs, 555-574. In JANSONIUS, J. \& McGregor, D.C. (eds) Palynology: principles and applications. American Association of Stratigraphic Palynologists Foundation vol. 2.

RichARDSON, J.B. \& LisTeR, T.R. 1969. Upper Silurian and Lower Devonian spore assemblages from the Welsh Borderland and South Wales. Palaeontology 12(2), 201-252.

Richardson, J.B. \& McGregor, D.C. 1986. Silurian and Devonian spore zones of the Old Red Sandstone Continent and adjacent regions. Bulletin, Geological Survey of Canada 364, 1-79. DOI 10.4095/120614

Richardson, J.B., Rodriguez, R.M. \& Sutherland, S.J.E. 2001. Palynological zonation of Mid-Palaeozoic sequence from the Cantabrian Mountains, NW-Spain: implications for inter-regional and interfacies correlation of the Ludford/Pridoli and Silurian/Devonian boundaries, and plant dispersal patterns. Bulletin of the Natural History Museum London (Geology) 57(2), 115-162.

Riegel, W. \& Karathanasopoulos, S. 1982. Palynological criteria for the Siegenian/Emsian transition in the Rhineland. Courier Forschungsinstitut Senckenberg 55, 199-206.

RodrígueZ, R.M. 1983. Palinologia de las formaciones del Silúrico superior-Devonico inferior de la Cordillera Cantabrica, noroeste de Espana. Servicio de Publicaciones de la Universidad de León, 1-231.

Schindler, T., Sutcliffe, O.E., Bartels, C., Poschmann, M. \& WutTKE, M. 2002. Lithostratigraphical subdivision and chronostratigraphical position of the middle Kaub Formation
(Lower Emsian, Lower Devonian) of the Bundenbach area (Hunsrück, SW Germany). Metalla 9(2), 73-88.

Schulz, G., 1968. Eine unterdevonische Mikroflora aus den Klerfer Schichten der Eifel (Rheinisches Schiefergebirge). Palaeontographica B 123, 5-42.

SChulze, F., 1855. Bemerkungen über das Vorkommen wohlerhaltener Cellulose in Braunkohle und Steinkohle. Bericht der Königlichen Preussischen Akademie der Wissenschaften zu Berlin 21, 676-678.

Solle, G. 1950. Obere Siegener Schichten, Hunsrückschiefer, tiefstes Unterkoblenz und ihre Eingliederung ins Rheinische Unterdevon. Geologisches Jahrbuch 65, 299-380.

SPIES, E.D. \& STETS, J. 2004. Geologie und Böden im westlichen Hunsrück (Exkursion C am 15.04.2004). Jahresberichte und Mitteilungen des Oberrheinischen Geologischen Vereines, Neue Folge 86, 77-108.

Steemans, P. 1989. Etude palynostratigraphique du Dévonien inférieur dans l'ouest de l'Europe. Mémoires pour servir à l'Explication des Cartes Géologiques et Minières de la Belgique 27, 1-453.

Stets, J. 1962. Zur Geologie der Drohntal Schichten und Hunsrückschiefer (Unterdevon) im Gebiet von BernkastelNeumagen-Thalfang (Hunsrück, Rheinisches Schiefergebirge). Notizblatt des Hessischen Landesamtes für Bodenforschung zu Wiesbaden 90, 132-159.

Stets, J. \& SchÄfer, A. 2009. The Siegenian delta: land-sea transitions at the northern margin of the Rhenohercynian Basin, 37-72. In Königshof, P. (ed.) Devonian change: Case studies in palaeogeography and palaeoecology. Special Publication, Geological Society of London 314.

DOI $10.1144 / \mathrm{sp} 314.3$

Stets, J. \& SchÄFeR, A. 2011. The Lower Devonian Rhenohercynian Rift $20 \mathrm{Ma}$ of sedimentation and tectonics (Rhenish Massif, W-Germany). Zeitschrift der deutschen Gesellschaft für Geowissenschaften 162(2), 93-115. DOI 10.1127/1860-1804/2011/0162-0093

Streel, M., Higgs, K., Loboziak, S., Riegel, W. \& Steemans, P. 1987. Spore stratigraphy and correlation with faunas and floras in the type marine Devonian of the Ardenne-Rhenish regions. Review of Palaeobotany and Palynology 5, 211-229. DOI 10.1016/0034-6667(87)90001-7

TAPPAN, H. \& LOEBLICH, R. 1971. Surface sculpture of the wall in Lower Paleozoic acritarchs. Micropaleontology 17(4), 385-410. DOI 10.2307/1484870

TibBs, S.L., BRIGgs, D.E.G. \& PRössL, K.F. 2003. Pyritisation of plant microfossils from the Devonian Hunsrück Slate of Germany. Paläontologische Zeitschrift 77, 241-246. DOI 10.1007/BF03004571

Traverse, A. 2007. Paleopalynology, second edition, 814 pp. In Landman, N.H. \& Jones, D.S (eds) Topics in geobiology. Springer Verlag, Dordrecht.

Uutela, A. \& Tynni, R. 1991. Ordovician acritarchs from Rapla borehole, Estonia. Bulletin of the Geological Survey of Finland 353, 1-135.

Wildberger, J. 1992. Zur tektonischen Entwicklung des südwestlichen Hunsrücks (SW-Deutschland). Mitteilungen der Pollichia 79, 5-119. 


\section{Appendix}

Table 1. Palynomorphs identified in the Siesbach section (Zerf Formation).

\section{Cryptospores}

cf. Acontotetras inconspicuis Richardson

Gneudnaspora divellomedia (Chibrikova) Burgess \& Richardson Tetrahedraletes medinensis (Strother \& Traverse) emend. Wellman \& Richardson

\section{Trilete spores}

Ambitisporites sp.

?Aneurospora cf. richardsonii (Rodriguez) Richardson et al. Apiculiretusispora brandtii Streel

Apiculiretusispora plicata (Allen) Streel

Apiculiretusispora sp.

Calamospora sp.

Cymbosporites aff. echinatus Richardson \& Lister.

Cymbosporites sp.

Dibolisporites sp.

Dictyotriletes cf. subgranifer McGregor

Dictyotriletes sp.

Emphanisporites rotatus (McGregor) McGregor

Emphanisporites cf. rotatus

Emphanisporites cf. protophanus Richardson \& Ioannides

Emphanisporites cf. multicostatus Rodriguez

Leiotriletes sp.

Retusotriletes dittonensis Richardson \& Lister

Retusotriletes maculatus McGregor \& Camfield
Retusotriletes rotundus (Streel) Streel

Retusotriletes, small tetrads

Streelispora newportensis (Chaloner \& Streel) Richardson \&

Lister

Streelispora $\mathrm{sp}$.

Zonate trilete spore indet.

\section{Prasinophytes}

Cymatiosphaera sp.1

Cymatiosphaera sp. 2

Dictyotidium cf. cavernulosum Playford

Tasmanites sp.

Prasinophyte indet.

\section{Acritarchs}

Baltisphaeridium spp.

Gorgonisphaeridium spp.

Lophosphaeridium sp.

Micrhystridium stellatum Deflandre

Micrhystridium spp.

Multiplicisphaeridium cf. albanegum Cramer et al.

Multiplicisphaeridium cf. ramusculosum (Deflandre) emend.

Lister

Multiplicisphaeridium sp.

Veryhachium trispinosum (Eisenack) Stockmans \& Willière 